\title{
El camí de la tasca a l'activitat en un context AICLE
}

\author{
Núria Tapias Nadales \\ Universitat Autònoma de Barcelona, Barcelona, Espanya
}

(Article rebut el 16 de novembre de 2010; versió final rebuda el 5 d'abril de 2011)

\begin{abstract}
Estudi dut a terme dins de l'equip col-laboratiu CLIL-SI, sobre el treball en petit grup en una aula AICLE de ciències en anglès. Parteix d'una perspectiva sociocultural de l'aprenentatge, parant especial atenció a la distinció entre tasca (material proposat pel docent) i activitat (allò que els alumnes fan per a realitzar la tasca de manera comunicativa) que proposa la Teoria de l'Activitat. L'objectiu és comprendre millor la dinàmica de grup en el desenvolupament d'una tasca AICLE, i observar les instàncies d'integració de continguts i llengua, per la qual cosa es descriuen i categoritzen les activitats que fan els alumnes. Això pot ser d'utilitat per a la reflexió de la pràctica docent, així com la formació del professorat.
\end{abstract}

\section{Introducció}

En els últims anys ha anat augmentant l'interès per l'AICLE (Aprenentatge Integrat de Continguts i Llengua Estrangera), fet que podem observar tant en la seva progressiva implementació a nombroses escoles i diferents nivells educatius, com en el nombre de treballs de recerca que s'han dut i s'estan duent a terme - serveixi d'exemple el treball del grup de recerca CLIL-SI ${ }^{1}$, dins del qual es troba aquesta recerca.

Com a docents, com és el meu cas, quan ens enfrontem a una aula AICLE per primer cop, ens envolten nombrosos dubtes i, sovint, por. Molta por. Por al desconegut, a les reaccions de l'alumnat, a que ens manquin coneixements: bé de contingut -si som especialistes en llengua-, bé de llengua - en el cas dels especialistes en la matèria. Sovint entrem a l'aula per primer cop amb certs coneixements teòrics, i carregats de bones intencions, però amb poca o cap experiència. Tot plegat fa que, malgrat el que hem après i els consells rebuts, conscient o inconscientment, acabem recorrent a les antigues ‘tècniques' que els nostres professors feien servir (sí, aquelles que ens vam prometre de desterrar per sempre més).

És generalment acceptat que el treball en petit grup propicia l'aprenentatge de l'alumnat i en canvi pocs docents i en poques ocasions l'apliquen a les aules. Per què? Potser per desconfiança envers al nostre alumnat, perquè creiem que no treballaran, o 
per por a perdre el temps o fins i tot el control de la situació. I és que el docent té un sentit de la propietat molt arrelat: la meva aula, els meus alumnes, el meu temps i, sobretot, el meu coneixement. Però, de debò ens pertanyen? Cal superar aquesta desconfiança a perdre el control absolut de la situació per cedir-ne una part als alumnes, i ho podem aconseguir promovent el treball en petit grup. Per això hem de saber què passa en aquell petit cercle que els alumnes creen quan treballen plegats.

Aquesta recerca s'ha dut a terme partint d'una perspectiva sociocultural i interaccionista de l'aprenentatge en general i de l'adquisició de la llengua en particular, la qual considera l'aprenentatge de llengües com a eina de socialització dels aprenents. Aquest treball es centrarà en la manera com un grup d’alumnes, mitjançant la interacció, desenvolupa un cert nombre d'activitats per dur a terme la tasca ${ }^{2}$ proposada per la docent. Per a poder comprendre aquest procés s’han revisat diverses perspectives teòriques que es resumiran a continuació.

Arribats a aquest punt, s'analitzen les dades multimodals (àudio, vídeo, fotografies, diari de camp, treball final i esborranys) en profunditat mitjançant l'anàlisi sociocultural del discurs. Ens hem centrat en el procés d'execució de la tasca, mirant de relacionar el procés amb les instruccions donades per la docent i amb el producte final, amb l'objectiu de comprendre millor què és el que succeeix quan un grup d'alumnes interactuen i co-construeixen coneixement, és a dir com es produeix l’aprenentatge.

\section{Marc teòric i metodològic}

Com ja hem esmentat, aquesta recerca parteix d'una perspectiva sociocultural i interaccionista de l'aprenentatge, segons la qual "the nature of human activity is that knowledge is shared and people jointly construct understandings of shared experience”3 (Mercer 2004: 138-139). Per a què l'aprenentatge sigui situat, cal un context autèntic que faci que aquest sigui significatiu (Lave 1991). Així mateix l'aprenentatge es produeix mitjançant la interacció, i sovint de manera col-laborativa (Mercer 1995; Richards i Lockhart 1996) i amb l'ajuda de bastides (Wood, Bruner i Ross 1976) en comunitats de pràctica ${ }^{4}$ (Lave 1991).

Dins de la perspectiva sociocultural, s’ha pres com a referència la diferenciació entre tasca i activitat, proposada per Coughlan i Duff (1994), segons la qual tasca és el material dissenyat pel docent mentre que activitat és l'apropiació de la tasca per part dels alumnes per a dur-la a terme de manera comunicativa. 
D’altra banda, donades les característiques de la tasca proposada a les alumnes, s'han tingut en compte aspectes relacionats amb els processos d'aprenentatge de l'escriptura en segones llengües i les seves especificitats. Tenint en compte la perspectiva sociocultural del llenguatge, l'escriptura, tant en L1 com en LE, es caracteritza per la seva construcció a partir de la representació de la llengua oral, per la no presència dels interlocutors i per la seva motivació. Aquests tres factors condicionaran tot el procés de composició i requeriran la presa de consciència de la llengua en la seva globalitat, doncs l'escriptor cal que pensi també com a lector. Amb tot, l'escriptura en LE presenta particularitats, que principalment sorgeixen del menor coneixement d'aquesta llengua i la consegüent no-automatització, fet que sovint es tradueix en una menor planificació i revisió del text i la necessitat d'emprar més temps per a la seva producció, per la qual cosa es comú el recurs a la L1 com a estratègia facilitadora o bastida (Guasch 2001).

Vist això, podem afirmar que l'AICLE sembla fet a mida per assolir aquests objectius, doncs ofereix un context autèntic per a que l'aprenentatge de llengües sigui un aprenentatge situat i afavoreixi la cooperació en comunitats de pràctica. Existeixen nombroses definicions d’AICLE, però optem per la proposada per Escobar (2009):

El AICLE engloba aquellas realidades educativas que consisten en la enseñanza y aprendizaje de materias curriculares o contenidos académicos mediante una lengua vehicular en desarrollo, de la cual los aprendices tienen una competencia comunicativa incipiente o avanzada, y que promueven de forma explícita:

- El mantenimiento y desarrollo de la lengua o lenguas primeras del aprendiz.

- Un enfoque auténticamente integrado. (p. 47)

Aquest treball consisteix en una recerca de caire etnogràfic duta a terme a l'aula com a eina d’auto-formació (Allwright i Bailey 1991; Wajnryb 1992). Qui fa la recerca és la docent que imparteix la matèria i saber què és el que passa en els petits grups mentre treballen serà útil, entre d'altres, per a la revisió de les tasques proposades i per a l’elaboració de noves.

Les dades han estat transcrites de manera acurada i analitzades mitjançant l'anàlisi sociocultural del discurs (Mercer 2004), el qual analitza el procés de creació conjunta de coneixement i la seva relació amb els resultats. Hem tingut en compte tant les marques transcòdiques -code-switching i interferències- (Nussbaum 2006), comunes en contextos d'aprenentatge de segones llengües com el paper de la gravadora, la qual actua sovint com a representant de la docent (Nussbaum 2001). 


\section{Context i dades de la recerca}

Les dades es van recollir en una escola concertada femenina del Vallès Occidental, en una aula AICLE de 1r d’ESO en la qual s’impartia Science - ciències en anglès. La tasca proposada forma part de la unitat didàctica Building Blocks, la qual introdueix, entre d'altres, els conceptes d'àtoms i molècules. La tasca consistia en fer un petit treball sobre la història de l'àtom, per a la qual cosa l'alumnat primer havia de buscar individualment informació sobre la història de l’àtom. A continuació, calia posar en comú la informació i fer-ne un petit resum en grups de 4 alumnes. Un cop acabats els resums, en grups s'havia de discutir quins havien estat els aspectes més importants que s’havien après gràcies al projecte. Finalment, es feina una posada en comú de les conclusions en un debat amb tota la classe guiat per la docent. Aquesta darrera tasca permetia a l'alumnat comprendre la diferència entre hipòtesi i teoria científica, així com a veure la importància del mètode científic.

Per a la recerca s'han utilitzat dades multimodals: enregistraments d'àudio i vídeo, fotografies, el diari de camp de la docent i els esborranys i treballs finals de les alumnes. S'han transcrit les gravacions corresponents a les instruccions de la primera i segona part de la tasca i de la interacció d'un grup mentre du a terme la segona part de la tasca. S'ha triat el grup que, segons una primera anàlisi de les dades, fa un major esforç per mantenir la llengua anglesa al llarg de tota la interacció, fet que indica el seu compromís amb la tasca.

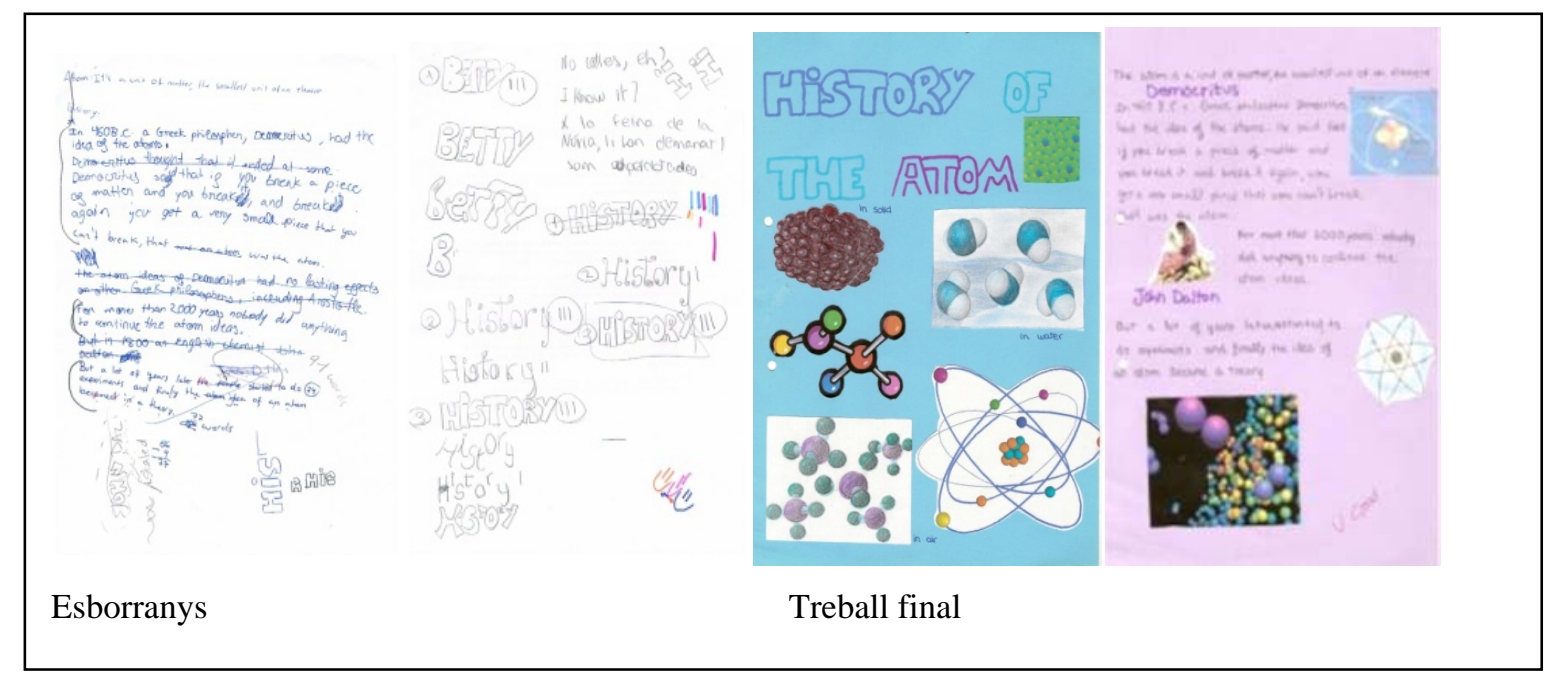

Figura 1: Dades escrites: esborranys i treball final de les alumnes 
Un cop fetes les transcripcions, s'ha realitzat una lectura paral·lela d'aquestes amb la resta de dades, mirant de relacionar-les i de categoritzar les activitats que duen a terme les alumnes durant l'execució de la tasca i parant especial atenció a les activitats d’integració de llengua i continguts.

\section{Categories sorgides de l'anàlisi}

De l'anàlisi de les dades hem pogut observar que, al llarg de la interacció, les alumnes duen a terme nombroses activitats orientades a l'assoliment del seu objectiu: realitzar un treball sobre la història de l’àtom. L’assignació d'activitats no és exclusiva per a cada torn, és a dir, en un mateix torn es poden realitzar diverses activitats, i per tant es podrà assignar a categories funcionals diferents. En primer lloc mostrem les categories que han sorgit de l'anàlisi de les dades:

- Gestió de la tasca:

o Organització

o Interpretació i dubtes

o Rols

o Valoració i estratègies afectives

- Activitats fora tasca

- Bastides / Co-Construcció

o Interpersonals

o L1

- Focalització en la llengua

o Reparacions

o Altres

- Focalització en el contingut

o Científic

0 Històric

o Artístic

- Integració

A continuació presentem alguns exemples de manera detallada. Una de les activitats que realitzen les alumnes és la de gestió de la tasca, les quals estan orientades a organitzarne la seva execució. N’hi ha de diferents tipus, en aquesta recerca hem observat activitats de gestió relacionades amb l’organització de la tasca, la seva interpretació i el plantejament i resolució dels dubtes que sorgeixen quan han de dur-la a terme, els rols de les alumnes i de la gravadora i també la valoració i altres estratègies afectives de les alumnes envers la tasca. L’exemple que proposem té a veure amb la interpretació de la tasca (al llarg del text s’han utilitzat pseudònims per a identificar les alumnes participants, amb l'objectiu de preservar el seu anonimat). 


\section{Exemple 1}

\begin{tabular}{|c|c|c|}
\hline Torn & Parlant & Text \\
\hline 73. & LAU: & we have to write a summary \\
\hline 74. & MAR: & a summary/ \\
\hline 75. & LAU: & yes \\
\hline 76. & JUL: & with our own (..) \\
\hline 77. & JEN: & words (3.0) \\
\hline 78. & MAR: & sixty or seventy words right/ \\
\hline 79. & JEN: & what/ \\
\hline 80. & MAR: & sixty or seventy words $\backslash$ ok \\
\hline 81. & JUL: & that's impossible because here's a lot (2.0) \\
\hline 82. & MAR: & sixty or seventy words there's no:: there's no: (xx) \\
\hline 83. & STU: & and $(\mathrm{xx})$ \\
\hline 84. & MAR: & yeah \\
\hline 85. & STU: & sixty or seventy words: \\
\hline 86. & MAR: & it's very: it's very little, yes \\
\hline 87. & STU: & yes \\
\hline 88. & MAR: & yes \\
\hline 89. & STU: & $\mathrm{i}$ am $\mathrm{i}$ am the \\
\hline 90. & JUL: & no but if we, no no if we $()<$. look $>$ \\
\hline 91. & MAR: & ahh/ \\
\hline 92. & JUL: & if we: if (.) \\
\hline 93. & STU: & $(\mathrm{xxx})$ \\
\hline 94. & STU: & no $()$. \\
\hline 95. & STU: & $(\mathrm{xxx})$ \\
\hline 96. & JUL: & no:/ if we plus all the: all our letters we have a lot (.) more of sixty or seventy \\
\hline 97. & JEN: & one thing (.) marta/ \\
\hline 98. & LAU: & but this is +minim+ \\
\hline 99. & JUL: & ah:/ ok \ \\
\hline
\end{tabular}

La tasca proposava fer un resum d'unes 60 o 70 paraules, però podem veure com a les alumnes els sembla poc per la quantitat d'informació que tenen (t. 86) i interpreten que 60 o 70 deu ser el nombre mínim de paraules (t. 98). Determinar el nombre de paraules és una activitat molt important per a elles i es reflexa també en els seus esborranys: 


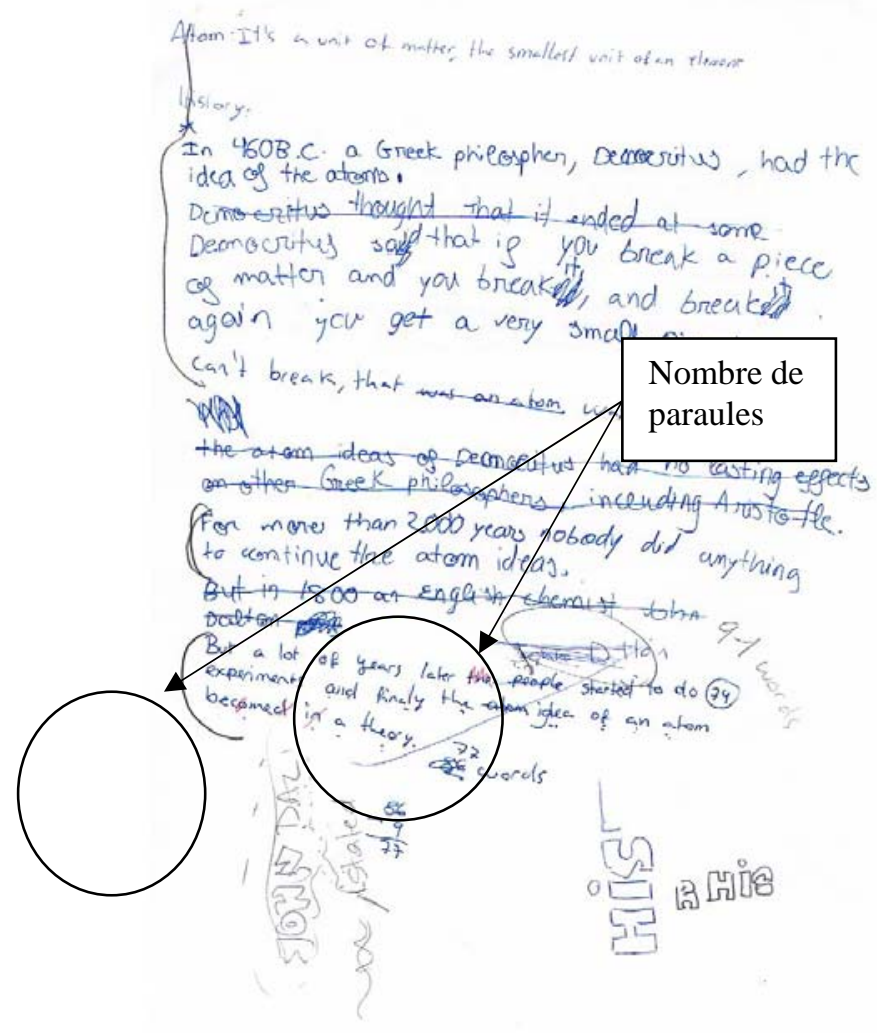

Figura 2: Nombre de paraules a l'esborrany

Hem pogut observar que les alumnes dediquen la major part del temps a treballar, però en ocasions es realitzen activitats fora tasca, que són aquelles activitats sense relació amb la tasca que l'alumnat realitza (Horrillo 2009). En aquest cas, es trobaran fora tasca sempre que no parlen de la història de l'àtom o de com dur a terme la tasca. Com podem veure a l'exemple, aquests moments fora tasca sovint són útils, ja que serveixen de relaxació per a les alumnes quan es troben en situacions de tensió o bloqueig i facilita la seva posterior predisposició per a l'aprenentatge.

\section{Exemple 2}

\begin{tabular}{|c|c|c|}
\hline Torn & Parlant & Text \\
\hline 105. & JUL: & have you got a tissue/ \\
\hline 106. & MAR: & $\mathrm{a} /$ \\
\hline 107. & JUL: & a tissuel \\
\hline 108. & MAR: & no (.) i finished the tissues \\
\hline 109. & JUL: & laural \\
\hline 110. & JEN: & $\begin{array}{l}\text { one question (.) } \\
\text { i don't know if i have to [(xxx) the text] }\end{array}$ \\
\hline 111. & JUL: & $\begin{array}{l}\text { [LAURA/] LAURA/ (.) LAURA/ LAURA/ } \\
\text { have you got a tissue/ }\end{array}$ \\
\hline 112. & MAR: & no: \\
\hline 113. & LAU: & yes i have (..) \\
\hline 114. & JUL: & can you (.) give me one please $\backslash$ (14.0) ok\ (..) and well (.) thank you laura very \\
\hline
\end{tabular}




\begin{tabular}{|c|c|c|}
\hline & & much (..) i'm very +encostipeit+ (2.0) it's a jokel \\
\hline 115. & JEN: & $\begin{array}{l}\text { ah: ((riure)) (4.0) oh:/ this is made up of paper } \backslash(1.0) \text { i have some tissues that } \\
\text { are made up of em: like }\end{array}$ \\
\hline 116. & JUL: & of cloth \\
\hline 117. & JEN: & of cloth \\
\hline 118. & JUL: & me also \\
\hline 119. & JEN: & $\begin{array}{l}\text { ah: i sometimes bring the cloth one but but it doesn't (.) it's a little bit } \\
\text { discusting o: (6.0) i know that (xxx)- }\end{array}$ \\
\hline 120. & JUL: & work jenny work \\
\hline
\end{tabular}

En aquest fragment es pot observar que després d'alguns torns fora tasca (t. 105-119), la Júlia insta a la resta a tornar a treballar (t.120). Sembla que la petita conversa no relacionada amb la tasca els ha servit d'esbarjo i pot facilitar la represa de la feina.

Quan les alumnes es troben amb dificultats, sovint recorren a bastides per a superar-les. Aquestes poden ser de diversa naturalesa: de vegades recorren a la seva llengua materna, d'altres necessiten l'ajuda d' algú altre més expert, en aquest cas la professora.

Exemple 3

\begin{tabular}{|c|c|c|}
\hline Torn & Parlant & Text \\
\hline 322. & TEA: & $\begin{array}{l}{ }^{\mathrm{o}}(\mathrm{xxx}) \text { (so what it) says here is that if you have a piece of (paper) and you break } \\
\text { it and break it (..) and break it again (..) in the end (you can't break it any more) } \\
(\mathrm{xxx})^{\mathrm{o}}(17.0)\left(\left(\text { se senten veus de nenes)) }{ }^{\circ} \text { again and again and again in the end }\right.\right. \\
(\mathrm{xxx})^{\mathrm{o}}\end{array}$ \\
\hline 323. & JEN: & this (.) this what $\backslash$ \\
\hline 324. & ALL: & no: \\
\hline $\begin{array}{l}325 . \\
(\ldots)^{5}\end{array}$ & LAU: & democritus \\
\hline 333. & LAU: & well em: said (.) that (.) if you break some matter- \\
\hline 334. & JEN: & they they \\
\hline 335. & LAU: & say (.) that if you (9.0) \\
\hline 336. & JEN: & and you break it and break it again a lot of times (.) you have to cop- \\
\hline 337. & LAU: & and you break it \\
\hline 338. & JEN: & a lot of times \\
\hline
\end{tabular}

De l'enregistrament podem deduir que l'explicació (t.323) estava dirigida a un altre grup, però serveix de bastida també a aquest. Laura i Jenny han entès el contingut i el reformulen conjuntament (t.325, 333-338), és a dir, es dóna una co-construcció, imitant estructures lingüístiques de la professora, com l'ús del condicional. En aquest cas ens trobem també amb una instància d’AICLE, ja que es dóna aprenentatge de contingut i de llengua.

La co-construcció, com a redactat conjunt consensuat explicatiu de l’àtom, que han dut a terme les alumnes la podem veure reflectida tant a l'esborrany com al treball final: 

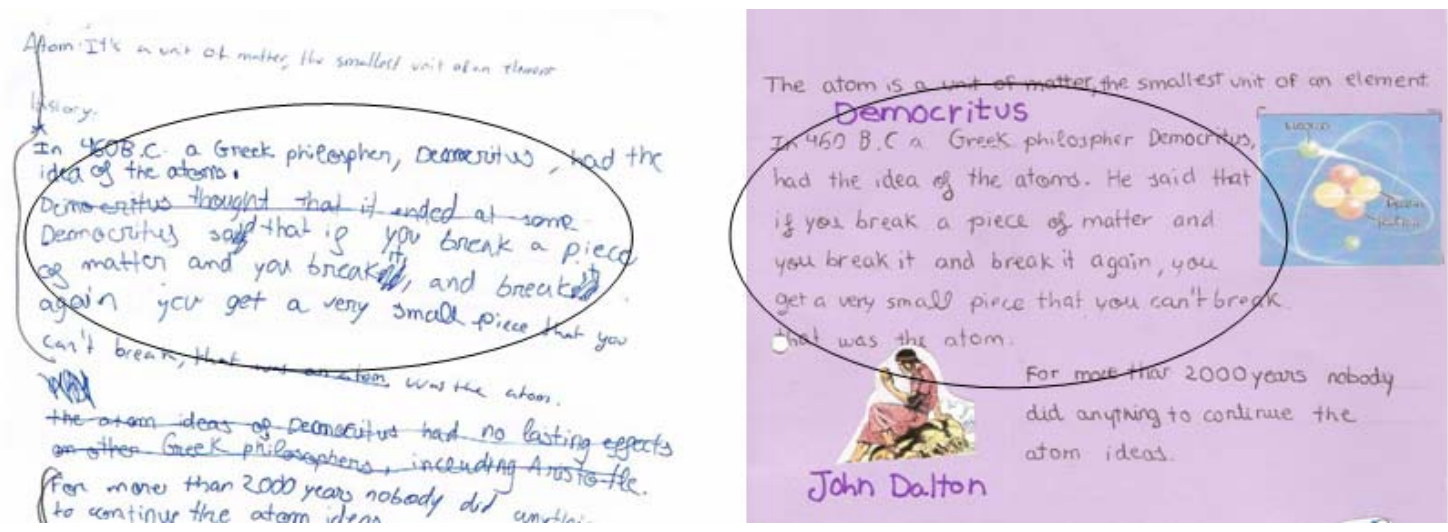

Figura 3: Co-construcció del text

L'execució de la tasca proposada per la docent implica la necessitat de focalitzar diferents aspectes. Aquesta ha estat la part més complexa en l'anàlisi de les dades, ja que no sempre és evident quin és l'aspecte que prioritzen les alumnes o si bé s'està donant un enfocament realment integrat.

En determinades instàncies, les alumnes paren atenció a aspectes lingüístics. En alguns casos es fixen en la forma, en les paraules, i es donen auto-reparacions. Com podem veure en el següent exemple, en què la Marta intenta explicar que estan resumint. Ella coneix la paraula "summary” i intenta derivar-lo com a verb (t.291), però davant la incomprensió de la companya (t.292) opta per la forma que coneix (t.293):

Exemple 4

$\begin{array}{ccl}\text { Torn } & \text { Parlant } & \\ \text { 291. } & \text { MAR: } & \text { we are +sumarian+ } \\ \text { 292. } & \text { STU: } & \text { what/ } \\ \text { 293. } & \text { MAR: } & \text { we are summary (..) what is what is the- }\end{array}$

En altres casos, com en l'exemple 5, les alumnes no focalitzen aspectes formals de la llengua sinó que negocien la manera d'executar una tasca lingüística: decideixen quin és el primer pas per a fer un resum (t.12-14), tal i com ho han après. Així l'activitat de gestió es centra en aspectes discursius.

Exemple 5

$\begin{array}{rrl}\text { Torn } & \text { Parlant } & \\ \text { 11. } & \text { JEN: } & \text { no (.) but, what do we have to do with this/ } \\ \text { 12. } & \text { MAR: } & \text { i: i: (.) i: m: prefer to: first- }(. .) \\ \text { 13. } & \text { JEN: } & \text { [underline] } \\ \text { 14. } & \text { JUL: } & \text { [underline] } \\ \text { 15. } & \text { MAR: } & \text { underline, ok } \backslash \\ \text { 16. } & \text { JEN: } & \text { [ok/] } \\ \text { 17. } & \text { JUL: } & \text { [ok/] me, too } \backslash \\ 18 . & \text { JEN: } & <\text { I'M GOING TO UNDERLINE NOW }>\end{array}$


En altres ocasions l'atenció del grup es centra en aspectes relacionats amb el contingut històric, científic i artístic. En l'exemple 6 podem observar com es posa l'enfocament en aspectes històrics relacionats amb l'àtom (t.284) i com conjuntament elaboren el text que es reflectirà en el producte final, com podem veure a la imatge 4. Exemple 6

\begin{tabular}{lcl} 
Torn & Parlant & \multicolumn{1}{c}{ Text } \\
284. & LAU: & $(\mathrm{xxx})$ in in this in the 460 bc $(\mathrm{xxx})$ a greek philosopher come with $(\mathrm{xxx})$ \\
285. & JEN: & eh: had $($.$) had the idea of the atom (.$.$) had the idea of the atom (3.0)$ \\
$(\ldots)^{6}$ & & \\
297. & LAU: & the idea of the atom (3.0) democritus \\
298. & MAR: & $(\mathrm{xxx})$ who found the atom and molecules (7.0)
\end{tabular}

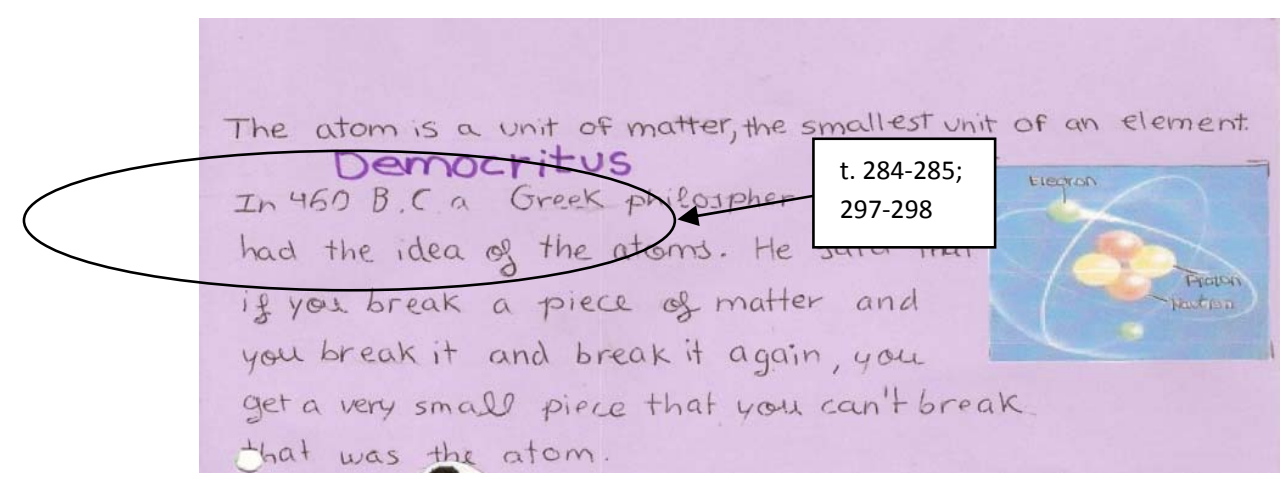

Figura 4: Contingut històric

En la majoria dels casos, però, les alumnes centren la seva atenció en aspectes artístics, de disseny del producte final. En l'exemple 7 podem observar com decideixen quins són els millors colors. El text que es produeix és multimodal, d'aquí la necessitat de focalitzar diferents tipus de llenguatges. La fotografia, l'esborrany i el producte final reflecteixen l’elecció del color, com podem observar en la figura 5:

\section{Exemple 7}

$\begin{array}{lll}\text { Torn } & \text { Parlant } & \\ 672 . & \text { JUL: } & \text { this one (4”) }{ }^{\circ} \text { ah } \text { vale }^{0} \text { who likes this/ } \\ 673 . & \text { LAU: } & { }^{\circ} \text { a veure }{ }^{0} \\ 674 . & \text { MAR: } & \text { i prefer this } \\ 675 . & \text { LAU: } & \text { i like (.) this } \\ 676 . & \text { MAR: } & \text { and me too } \\ 677 . & \text { JEN: } & \text { oi like this }{ }^{\circ} \\ 678 . & \text { MAR: } & \text { ok } \\ 679 . & \text { JEN: } & \text { but }(.) \text { is like this/- }(.) \text { ah/ is the normal one/ (.) } \\ & & \text { [but this is/] } \\ 680 . & \text { JUL: } & \text { [this is the normal] } \\ 681 . & \text { JEN: } & \text { but this is/ like }(.) \text { purple/ or is like:/ } \\ 682 . & \text { JUL: } & \text { no no }(.) \text { like this or like this } \\ 683 . & \text { MAR: } & \text { like this } \\ 684 . & \text { LAU: } & \text { yes }\end{array}$




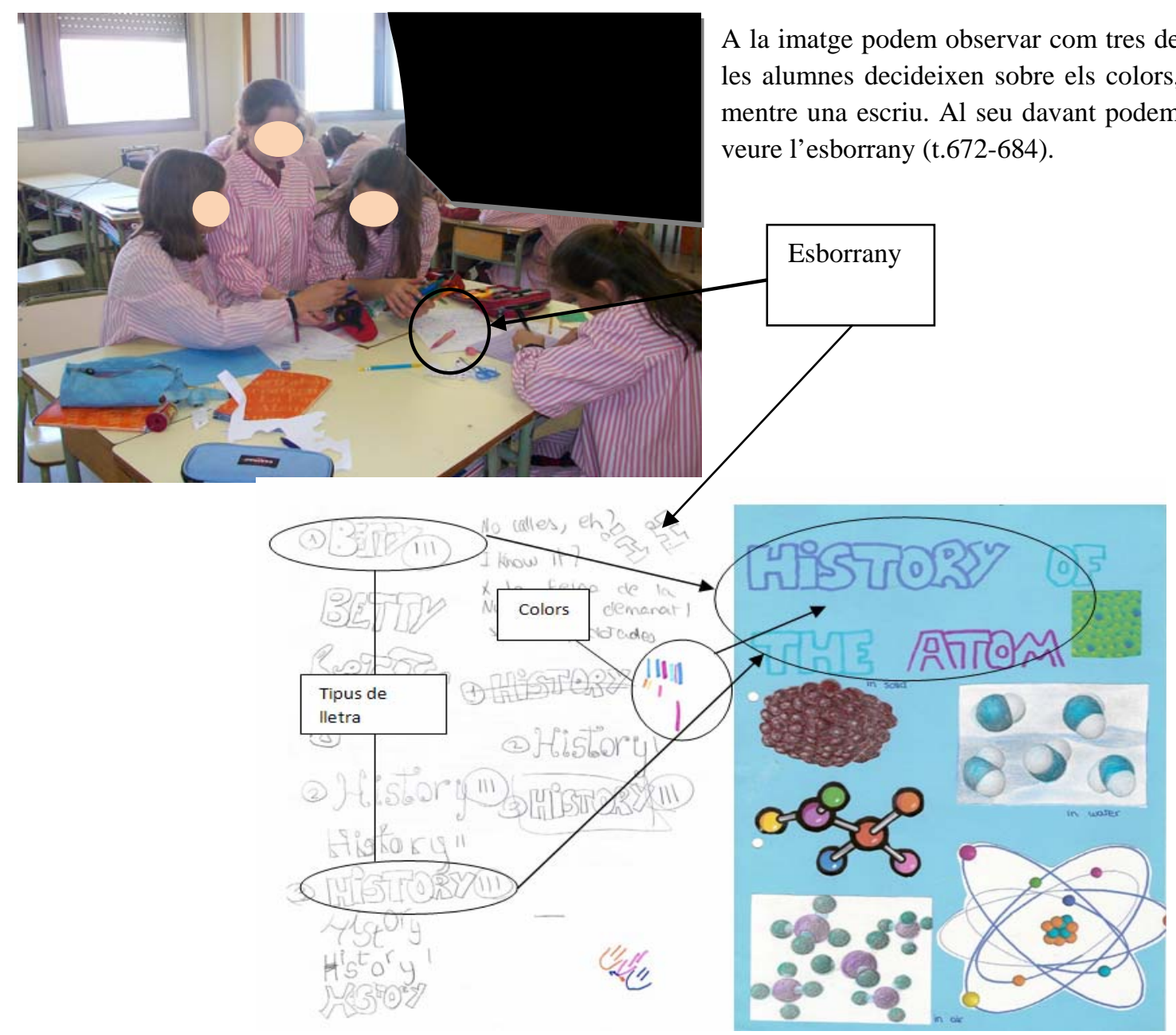

Figura 5: Contingut artístic

Durant l'execució de la tasca també s'han donat instàncies d'integració de llengua i contingut. Aquesta és la categoria clau a AICLE i s’ha assignat a aquells torns en què es pot observar l'adquisició de nous coneixements de llengua i contingut per part d'un alumne.

\section{Exemple 8}

\begin{tabular}{|c|c|c|}
\hline Torn & Parlant & Text \\
\hline 263. & LAU: & it is a unit of matter (.) the smallest unit of an element (xxx) \\
\hline 264. & MAR: & $\begin{array}{l}\text { i have (xxx) the information but i found that it's tales de mileto and then (.) it } \\
\text { finds another time (.) um: (.) arist- aristoles }\end{array}$ \\
\hline 265. & JUL: & but i don’t know \\
\hline 266. & LAU: & me democritus \\
\hline 267. & MAR: & ah yes and (..) democri- democrito um: \\
\hline 268. & LAU: & nuria $\quad[\mathrm{xxx}]$ \\
\hline 269. & MAR: & nuria that $[\mathrm{i}$ don't find the $(\mathrm{xxx})]$ but i i $[(\mathrm{xxx})]$ \\
\hline 270. & JEN: & $\begin{array}{l}\text { the word atom comes from the greek (.) a tomos and +siginifis }+ \text { indivisible (.) } \\
\text { was invented by (xxx) in } 220 \text { before jesus christ (.) this is important because is } \\
\text { when or who was invented the atom }\end{array}$ \\
\hline
\end{tabular}




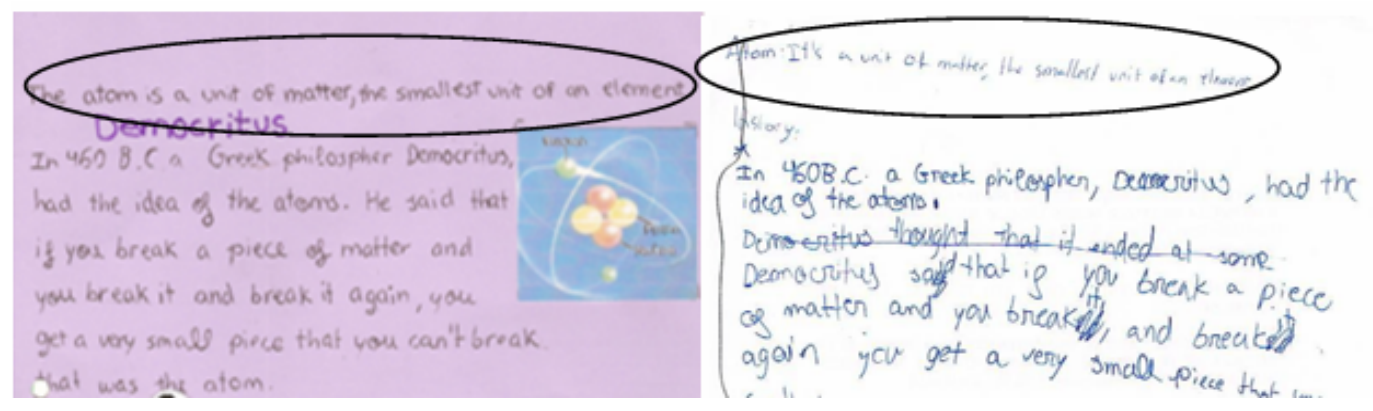

Figura 6: Definició d’àtom

Com podem observar, al llarg del fragment les alumnes enuncien la definició que apareix a l'esborrany i que finalment apareixerà en el producte final (t. 263), podem considerar que en aquest moment el contingut de la conversa és científic. En el torn següent es modificarà l'enfocament, passant a tantejar els aspectes històrics de la tasca, mirant de determinar l’origen de la paraula i del concepte en si mateix (t. 270), així com dels seus pensadors (t. 264, 266, 267). És especialment interessant el t. 270 com a mostra d'aprenentatge integrat de contingut i llengua, ja que podem observar clarament l'esforç de comprensió i reelaboració del contingut, que és la història dels orígens de l’àtom.

La incidència al llarg de la interacció d'aquest tipus d'intervencions en què es pot observar aprenentatge de continguts i llengua ha estat inferior a l'esperada, bé sigui pel propi disseny de la tasca - es tracta d'una tasca introductòria, de caràcter més "lingüístic” - que, juntament amb una certa manca de maduresa de l’alumnat, pot haver afavorit els aspectes més estètics de la tasca en front d'altres de contingut científic més evident. Ara bé, és possible que la integració no es doni en un torn concret i de manera evident sinó com a resultat del procés d’execució de tasques adientment dissenyades.

\section{Resum de les activitats}

De l'anàlisi de les dades, com ja s'ha esmentat anteriorment, han sorgit nombroses categories, que podem veure resumides en aquest quadre. Cada activitat pot ocupar un nombre de torns molt variable, per la qual cosa s'ha optat per comptabilitzar el nombre de torns invertits per a dur a terme cada activitat i no el nombre de cops que es repeteix cada activitat. D’aquesta manera podem observar la incidència cada activitat en la globalitat de la interacció. 
Taula 1: Resum d'activitats

\begin{tabular}{|c|c|c|c|}
\hline \multicolumn{2}{|c|}{ Activitat: } & \multicolumn{2}{|r|}{$\mathrm{N}^{\mathrm{o}}$ torns } \\
\hline \multicolumn{2}{|l|}{ Interacció (total) } & \multicolumn{2}{|l|}{782} \\
\hline \multicolumn{2}{|l|}{ Gestió de la tasca } & \multicolumn{2}{|l|}{211} \\
\hline \multicolumn{2}{|l|}{ Fora tasca } & \multicolumn{2}{|l|}{47} \\
\hline \multicolumn{2}{|l|}{ Bastides / Co-construcció } & \multicolumn{2}{|l|}{34} \\
\hline \multicolumn{2}{|l|}{ Focalització llengua } & \multicolumn{2}{|l|}{64} \\
\hline \multirow[t]{3}{*}{ Focalització contingut: } & Científic & 2 & \multirow[t]{3}{*}{430} \\
\hline & Històric & 58 & \\
\hline & Artístic (disseny) & 370 & \\
\hline \multicolumn{2}{|l|}{ Integració } & \multicolumn{2}{|l|}{11} \\
\hline
\end{tabular}

De la taula es desprèn que bona part de la interacció ha consistit en discutir aspectes artístics o en gestionar la tasca i no tant en la discussió d'aspectes de caire més científic, històric o lingüístic, malgrat els propòsits inicials de la mateixa. Com ja hem comentat anteriorment en parlar de les activitats d'integració, és possible que això hagi estat a causa del disseny de la pròpia tasca (tasca introductòria de caràcter més lingüístic i que promou aspectes estètics), o del grau maduresa de l'alumnat. També pot tractar-se d'un problema d'enfocament, és a dir, la integració podria no donar-se de manera evident en un únic torn (o petit fragment), sinó de manera progressiva al llarg de l’execució de la tasca.

\section{Conclusions}

En aquesta recerca podem observar la gran varietat d'activitats que sorgeixen d'una sola tasca proposada. Es tracta d'una tasca introductòria a la unitat didàctica titulada Building Blocks, que tracta sobre la matèria, i que es caracteritza per la seva priorització dels aspectes lingüístics respecte als aspectes científics -la part principal de la tasca i objecte de la recerca és l'elaboració d'un resum en grups-, però que malgrat tot ofereix certes oportunitats per a l'AICLE.

De l'anàlisi de les dades s’han pogut observar diverses categories d'activitats, la majoria enfocades a resoldre aspectes artístics i no tant de contingut o llengua, que és el que habitualment s'espera de tasques AICLE. D’altra banda apareixen poques instàncies en què es pugui observar de manera evident la integració de continguts i llengua. Ara bé, això no vol dir que aquesta integració no es doni, si no que es va construint intervenció rere intervenció, de manera que la integració de continguts i llengua és el resultat d'un procés llarg que fins i tot pot semblar poc “productiu”, però absolutament necessari. 
Podem considerar que la gran varietat d'activitats sorgides de l'execució de la tasca és indicativa del gran valor del treball en grup, del que habitualment només podem observar el producte final sense poder veure què passa mentre es realitza. És per això que és important promoure treball en petit grup en contextos que promoguin una interacció real, en què es construeixi coneixement a través principalment del llenguatge, en aquest cas d'una llengua diferent de l'habitual.

Així mateix, a la vista dels resultats obtinguts es fa evident la necessitat d'una bona programació de les tasques AICLE considerant tant objectius de contingut com de llengua i en què es busqui una autèntica integració d'ambdós aspectes. D’altra banda les categories emprades i analitzades poden ser d'utilitat per a la reflexió sobre la pràctica docent i per a la formació del professorat, així com per al disseny i implementació de tasques AICLE.

\section{Referències bibliogràfiques}

Allwright, D. i Bailey, K.M. (1991). Focus on the language classroom. An introduction to classroom research for language teachers. Cambridge: Cambridge University Press.

Atkinson, J.M. i Heritage, J. (1984). Structures of social action: Studies in conversation analysis. Cambridge: Cambridge University Press.

Coughlan, P. i Duff, P.A. (1994). Same task, different activities: Analysis of a second language acquisition task from an activity theory Perspective. A: Lantolf, J.P. i Appel, G. (eds.) Vygotskian approaches to second language research (pp. 173194). Norwood, N.J.: Ablex.

Escobar, C. (2009). Cuando la lengua de la escuela es diferente de la lengua familiar. Monográfico Aprender en ingles. Cuadernos de Pedagogía, 395: 46-51.

Guasch, O. (2001). L'escriptura en segones llengües. Barcelona: Graó.

Horrillo, Z. (2009). A study of the on-task and off-task activity carried out by teenage learners during a content and language integrated learning task. The International Journal of Language 16(11): 113-136.

Lave, J. (1991). Situated learning in communities of practice. A: Resnick, Levine y Teasley (eds.) Perspectives on socially shared cognition (pp. 63-82). Washington D.C.: American Psychological Association.

Mercer, N. (1995). The guided construction of knowledge: Talk among teachers and learners. Clevedon: Multilingual Matters.

Mercer, N. (2004). Sociocultural discourse analysis: analysing classroom talk as social mode of thinking. Journal of Applied Linguistics, 1(2): 137-168.

Nussbaum, L. (2001). El discurso en el aula de lenguas extranjeras. A: Nussbaum, L. i Bernaus, M. (eds.) Didáctica de la lengua extranjera en la ESO (pp. 137-172). Madrid: Síntesis.

Nussbaum, L. (2006). La transcripción de la interacción en contextos de contacto y aprendizaje de lenguas. A: Bürky, Y. i De Stefani, E. (eds.) Transcribir la lengua. De la filologia al análisis conversacional (pp. 195-217). Berna: Peter Lang. 
Richards, J.C. i Lockhart, C. (1996). Reflective teaching in second language classrooms. Cambridge: Cambridge University Press.

Wajnryb, R. (1992). Classroom observation tasks. A resourcebook for language teachers and trainers. Cambridge: Cambridge University Press.

Wood, D., Bruner, J.S. i Ross, G. (1976). The role of tutoring in problem solving. Journal of Child Psychology and Psychiatry, 17: 89-100.

\footnotetext{
Notes

${ }^{1}$ Equip d'investigadors/es que fan recerca col-laborativa en AICLE i la promouen entre professorat en actiu. http://grupsderecerca.uab.cat/clilsi/

${ }^{2} \mathrm{Al}$ llarg del treball es diferenciarà entre tasca i activitat, segons proposa la Teoria de l'Activitat.

3 "la naturalesa de l'activitat humana és que el coneixement és compartit i els individus construeixen una comprensió conjunta de l'experiència compartida” (Traducció de l'autora).

${ }^{4}$ Grup de persones que comparteixen un interès comú sobre un tema, i que aprenen sobre el mateix través de la interacció (Lave 1991).

${ }^{5}$ El fragment omès correspon a una conversa paral-lela entre les altres dues components del grup sobre aspectes artístics.

${ }^{6}$ El fragment omès correspon a una conversa paral-lela entre les altres dues components del grup sobre la gestió de la informació disponible.
}

\section{Annex: Simbologia de transcripció}

Adaptació de la simbologia proposada per Gail Jefferson (Atkinson i Heritage 1984).

Entonació:

a. Descendent: \

b. Ascendent: /

Pauses:

a. Menys de mig segon: (.)

b. Més de mig segon: (..)

c. Més d'un segon: (1.0)

Torns solapats: [text]

Interrupció abrupta: text-

Allargament sil·làbic: text::

FORTE

${ }^{\circ}$ piano ${ }^{\circ}$

$<$ lento $>$

$>$ allegro $<$

Fragment incomprensible: $(\mathrm{xxxx})$

Transcripció fonètica aproximada: +text+

Enunciats en català: cursiva

Comentaris del transcriptor: ((text))

\section{Referència de l'autora}

Núria Tapias Nadales és llicenciada en Traducció i Interpretació (2001) a la Universitat Autònoma de Barcelona. És professora d'anglès a Secundària i participa en programes AICLE (Aprenentatge Integrat de Continguts curriculars i Llengua) del seu centre escolar. També és investigadora en procés de formació i està elaborant la seva tesi doctoral sobre la integració de continguts i llengua en contextos AICLE de ciències naturals.

Email: ntapias@hotmail.com 